\title{
Polihexanide: A Safe and Highly Effective Biocide
}

\author{
K. Kaehn \\ K2 Hygiene Dienstleistungen, Aschaffenburg, Germany
}

\section{Key Words}

Polihexanide - Polihexanide, chemical characteristics •

Biocide $\cdot$ Antiseptic $\cdot$ Wounds

\begin{abstract}
Polihexanide is a broad-spectrum antiseptic with excellent tolerance and a low-risk profile. The physicochemical action on the bacterial envelope prevents or impedes the development of resistant bacterial strains. Thus, polihexanide is particularly suitable and useful in the struggle against multidrug-resistant bacteria. The ecological database is still incomplete. There is some evidence that biodegradation requires adsorption to inert surfaces and that only a small number of bacterial species are capable of utilizing polihexanide.

Copyright $\odot 2010$ S. Karger AG, Basel
\end{abstract}

\section{Introduction}

Recently, on April 25, 2008, the first World Malaria Day was commemorated. The WHO established this day to raise awareness and understanding of malaria, which kills up to 3 million people per year around the world. The fight against malaria was the reason for in- tense research into biguanides. During a screening program for antimalaria drugs, chlorhexidine and polihexanide were first synthesized in the 1950s in the laboratories of ICI Ltd., UK [1]. These biguanides are broad-spectrum antimicrobial agents and are widely used for disinfection. Although the effect of chlorhexidine is primarily bacteriostatic, it was very successfully marketed for disinfection of skin and mucosa, while polihexanide, a heterogeneous mixture of a biguanide polymer, was used for about 40 years in nonmedical consumer applications. However, in the early 1990s, polihexanide was introduced into medicine for local antiseptic treatment by the Swiss surgeon Willenegger [2, 3]. Thenceforward, the use of polihexanide in medicine constantly increased: in wound care management, Kaehn and Eberlein [4] showed that cleansing with polihexanide-based products reduced bacterial load and infection rates of chronic wounds; Daeschlein et al. [5] reported beneficial effects in the treatment of burns; polihexanide was recommended as the therapy of choice for bacterial vaginosis [6], as an alternative for preoperative antiseptic treatment in cataract surgery [7], and as a substitute for antibiotics in local anti-infective treatment [8]. The action of polihexanide on phospholipid membranes was closely examined by Ikeda's group [912]. The cationic polymer polihexanide attached to neg-

\section{KARGER}

Fax +4161306 1234

E-Mail karger@karger.ch

www.karger.com
(C) 2010 S. Karger AG, Basel

$1660-5527 / 10 / 0237-0007 \$ 26.00 / 0$

Accessible online at: www.karger.com/spp
Kurt Kaehn, MSc, PhD

K2 Hygiene Dienstleistungen

Haidstrasse 48

DE-67431 Aschaffenburg (Germany)

Tel. +49602 144 7528, Fax + 49602144 7549, E-Mail k2-hygiene@t-online.de 
Table 1. Chemical characterization of polihexanide

\begin{tabular}{|c|c|}
\hline CAS No. & $50641-36-6$ \\
\hline Chemical name and synonyms & $\begin{array}{l}\text { Poly[imino(imidocarbonyl) imino(imidocarbonyl)iminohexamethylene monohydrochloride]; } \\
\text { poly(hexamethylene biguanide hydrochloride), PHMB }\end{array}$ \\
\hline General formula & $\begin{array}{l}\mathrm{R}-\left(\mathrm{CH}_{2}\right)_{6}-\left[-\mathrm{NH}-\mathrm{C}\left(=\mathrm{N}^{\oplus} \mathrm{H}_{2}\right)-\mathrm{NH}-\mathrm{C}(=\mathrm{NH})-\mathrm{NH}-\left(\mathrm{CH}_{2}\right)_{6}-\left\{\mathrm{Cl}^{-}\right\}\right]_{\mathrm{n}-1^{-}}-\mathrm{R} \\
(\mathrm{R}=\text { terminal groups })\end{array}$ \\
\hline Monomer to polihexanide & $\begin{array}{l}\text { 1-(6-aminohexyl)-3-cyanoguanidine } \\
\mathrm{NC}-\mathrm{NH}-\mathrm{C}(\mathrm{NH})-\mathrm{NH}-\mathrm{CH}_{2}-\mathrm{CH}_{2}-\mathrm{CH}_{2}-\mathrm{CH}_{2}-\mathrm{CH}_{2}-\mathrm{CH}_{2}-\mathrm{NH}_{2}\end{array}$ \\
\hline $\begin{array}{l}\text { Basic structure of biguanides } \\
\text { with antimicrobial activity }\end{array}$ & $\begin{array}{l}\mathrm{R}-\mathrm{HN}-\mathrm{C}(\mathrm{NH})-\mathrm{NH}-\mathrm{C}(\mathrm{NH})-\mathrm{NH}-\mathrm{CH}_{2}-\mathrm{CH}_{2}-\mathrm{CH}_{2}-\mathrm{CH}_{2}-\mathrm{CH}_{2}-\mathrm{CH}_{2}-\mathrm{NH}-\mathrm{C}(\mathrm{NH})-\mathrm{NH}-\mathrm{C}(\mathrm{NH})-\mathrm{NH}-\mathrm{R} \\
\text { ( } \mathrm{R}=4 \text {-chlorophenyl for chlorhexidine and amine and cyanoguanidine for polihexanide) }\end{array}$ \\
\hline $\begin{array}{l}\text { Reagents for polihexanide synthesis } \\
\text { (melt polymerization) }\end{array}$ & $\begin{array}{l}\text { 1,1'-(hexane-1,6-diyl)-bis(3-cyanoguanidine) } \\
\text { Synonym: } 1,6 \text {-di(cyanoguanidino)hexane } \\
\text { NC-NH-C(NH)-NH-CH}-\mathrm{CH}_{2}-\mathrm{CH}_{2}-\mathrm{CH}_{2}-\mathrm{CH}_{2}-\mathrm{CH}_{2}-\mathrm{NH}-\mathrm{C}(\mathrm{NH})-\mathrm{NH}-\mathrm{CN} \\
\text { and } 1,6 \text {-diaminohexane } \\
\mathrm{NH}_{2}-\mathrm{CH}_{2}-\mathrm{CH}_{2}-\mathrm{CH}_{2}-\mathrm{CH}_{2}-\mathrm{CH}_{2}-\mathrm{CH}_{2}-\mathrm{NH}_{2}\end{array}$ \\
\hline
\end{tabular}

atively loaded (anionic) phospholipids characteristic of bacterial membranes and finally interfered with the stability of these membranes. In contrast, the interaction with human and animal cells is very restricted, and thus an outstanding feature of polihexanide is the large safety margin, making the risk-benefit ratio superior to other antimicrobial agents [13].

Physiological effects of polihexanide on animals are restricted. Frieling et al. [14] induced systemic hypotension and topical vasodilation in the intestinal mucosa by intraperitoneal instillation of polihexanide in rats. Although the vasodilative effect and severe hypotension during peritoneal lavage was confirmed by Berg et al. [15] for guinea pigs, polihexanide has been used for a long time by clinicians for this application and without occurrence of adverse effects [Roth B., pers. commun.]. Kramer et al. [16] demonstrated significantly improved wound healing in experimental aseptic wounds treated with polihexanide. This effect is probably based upon both protection of collagen degradation shown in an in vitro test [17] and vasodilation in ear skin of hairless mice after topical polihexanide application [18]. Physiological effects on human and animal cells and tissues are currently a matter of intense investigation and discussion and are reviewed in detail in this issue [Hübner and Kramer, this supplement issue].

The present review focuses on major aspects of polihexanide coming to the forefront by increasing use in medical applications such as physicochemical properties, target sites and physiological and ecological compatibility.

\section{Polihexanide - Chemical Characterization}

The original observation in the 1950s was that polymeric biguanides were strongly antibacterial, while molecules carrying only one biguanide group were not. In a series of chemical syntheses and analyses, Rose and Swain [19] from ICI Ltd. (UK) revealed the molecular composition of biguanides for high antibacterial activity. In brief, the number (n) of biguanide residues must be $\geq 2$ and the optimal number of methylene groups in the spacer between the biguanide residues is $\mathrm{m}=5,6$, or 7 . This basic chemical structure is present in both chlorhexidine and polihexanide. In chlorhexidine $(\mathrm{n}=2, \mathrm{~m}=6)$, a terminal 4-chlorophenyl group is linked to each biguanide residue and in polihexanide $(\mathrm{n}=2-40, \mathrm{~m}=6)$, the terminal groups are amine and cyanoguanidine. 
Fig. 1. Model of polihexanide $(n=4)$ with a cyanoguanidino- and amino-terminal group (ArgusLab 4.0, Mark A. Thompson, Planaria Software LLC, Seattle, Wash., USA, http://www.arguslab.com; PoV Raytracer 3.6, Persistence of Vision Pty. Ltd., Williamstown, Vic., Australia, http:// www.povray.org).

$\mathrm{NC}-\mathrm{NH}-\mathrm{C}(\mathrm{NH})-\mathrm{NH}-\mathrm{CH}_{2}-\mathrm{CH}_{2}-\mathrm{CH}_{2}-$ [- $\mathrm{CH}_{2}-\mathrm{CH}_{2}-\mathrm{CH}_{2}-\mathrm{NH}-\mathrm{C}(\mathrm{NH})-\mathrm{NH}-\mathrm{C}$ $\left.\left(\mathrm{N}^{\oplus} \mathrm{H}_{2}\right)-\mathrm{NH}-\mathrm{CH}_{2}-\mathrm{CH}_{2}-\mathrm{CH}_{2}-\left\{\mathrm{Cl}^{-}\right\}\right]_{4}-\mathrm{NH}_{2}$ $\mathrm{N}^{\oplus}=$ Violet; $\mathrm{N}=$ blue; chloride = green.

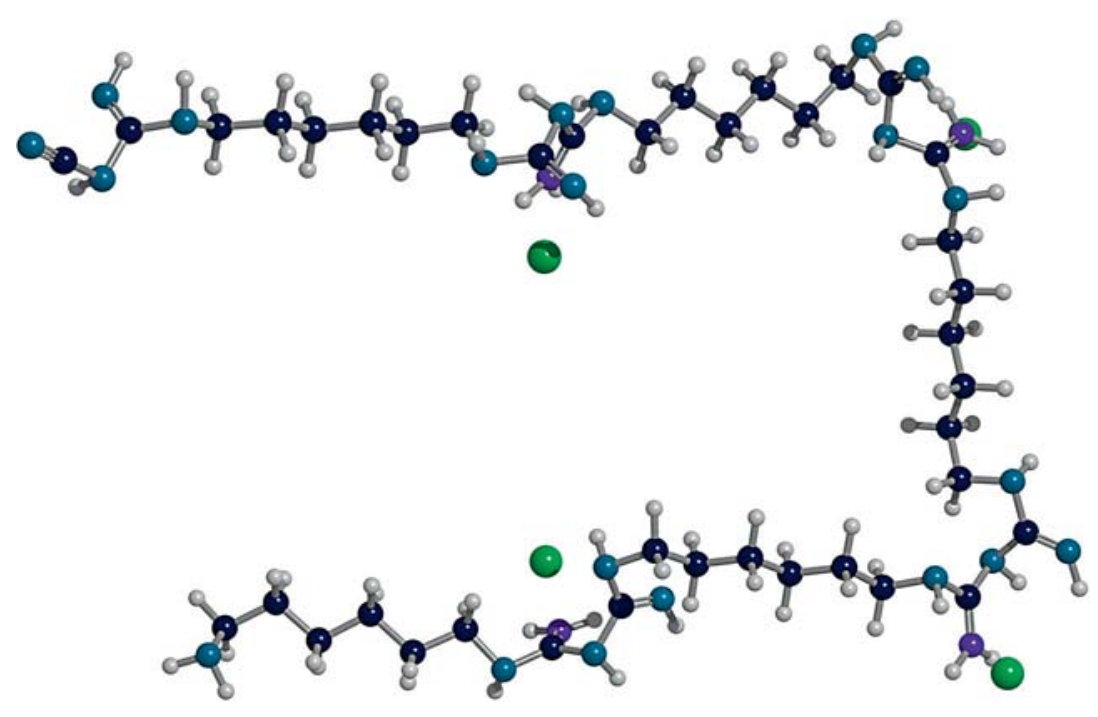

The monomer to polihexanide is 1-(6-aminohexyl)-3cyanoguanidine (table 1), and as detected by chromatographic methods, $75 \%$ of polymer chains are made up of $\mathrm{n}=2-5$ monomer units (polihexanide commercial product supplied by ICI Organics Division, Manchester, UK) [20]. Because of the method of synthesis, each polymer may have 2 amino-terminal groups, 1 amino- plus $1 \mathrm{cy}$ anoguanidino-terminal group, or 2 cyanoguanidino-terminal groups. Recently, 2 other terminal groups resulting from in-chain $\mathrm{C}-\mathrm{N}$ bond cleavage during synthesis of polihexanide were detected (Cosmocil ${ }^{\circledR} \mathrm{CQ}$, Avecia, Billingham, UK) [21]. Formally, these new groups can be derived from transfer of the cyano group $(-\mathrm{CN})$ of cyanoguanidine to the amino-terminal group (table 1). Regarding the polarity along the linear polymer, polihexanide consists of alternating hydrophilic biguanide residues and hydrophobic hexamethylene spacers flanked by hydrophilic polar or ionic terminal groups. Consequently, polihexanide is highly soluble in water $(20 \% \mathrm{w} / \mathrm{v})$ and aliphatic alcohols, but poorly soluble in lipids.

The biguanide residues in polihexanide are strong bases; the first imino group $(=\mathrm{NH})$ is $50 \%$ protonated $\left(=\mathrm{NH}_{2}^{+}\right)$at a $\mathrm{pH}$ value of about 11 and the second at about $2.5\left(\mathrm{pH}_{1}=10.5-11.5 ; \mathrm{pH}_{2}=2-3\right)[10,22]$. Thus, at a physiological $\mathrm{pH}$, biguanide residues are monoprotonated and polihexanide behaves as a polycation with a positive charge at each biguanide residue (fig. 1).

Polihexanide: A Safe and Highly Effective Biocide

\section{Polihexanide - Target Sites}

Davies et al. [23] studied the effect of polihexanide (Vantocil ${ }^{\circledR}$ ) on spheroplasts of Escherichia coli. In the concentration range of 2-20 mg polihexanide/l (corresponding to $0.01-0.1 \mathrm{~g} / \mathrm{l}$ Vantocil), no or only limited lysis occurred; however, release of UV-absorbing ${ }^{32} \mathrm{P}$ - and ${ }^{14} \mathrm{C}$ labelled materials was detected. At a polihexanide concentration of $60 \mathrm{mg} / \mathrm{l}$ precipitation of cytoplasm was induced, and at $120 \mathrm{mg} / \mathrm{l}$ the entire spheroplasts were converted into a single electron-dense particle. The authors concluded that polihexanide disorganizes the cytoplasmic membrane of microbes, leading to increased membrane permeability.

The attachment of polihexanide induces shifts in the physical properties of membranes. These shifts are suitable parameters for studying potential target sites of polihexanide on microbes in more detail. At a $\mathrm{pH}$ value of 7 , all membrane phosphoglycerides have a negatively charged phosphate group, while the alcohol component esterified to the phosphate group may be neutral but highly polar (i.e. glycerol) or positively charged (i.e. choline, ethanolamine). Thus, the net charge of phosphoglycerides is either neutral or negative, and the latter are possible target sites for the positively charged polihexanide.

Ikeda et al. [9] used fluorescence depolarization and differential scanning calorimetry methods [10] to record fluidity of phospholipid bilayers. They incubated poli- 
hexanide with liposomes prepared from different phosphoglycerides, which are found almost entirely in cytoplasmic membranes. Increased mobility of diphenylhexatriene probes embedded in the bilayers was used as a marker for increased fluidity. In the presence of the negatively charged phospholipid phosphatidylglycerol, addition of polihexanide to liposomes significantly increased the mobility of the diphenylhexatriene probes as detected by reduced fluorescence depolarization signals. In contrast, fluidity of single or mixed bilayers prepared from neutral phospholipids (phosphatidylcholine and phosphatidylethanolamine) was not significantly affected by the addition of polihexanide. These results were consistent with the view that polihexanide is adsorbed on negatively charged phospholipids and were confirmed by Ikeda et al. [12] in a study using 8-anilinonaphthalene-1-sulfonate as a fluorescent probe.

Differential scanning calorimetry reveals phase transitions (solid/liquid) in membranes during heating and separation of phospholipids in more fluid and rigid domains. Shifts to higher phase transition temperatures indicate tighter packing of phospholipid molecules, induced either by neutralization or cross-linking of phosphate groups. Ikeda et al. [10] found that addition of $20 \%$ $(\mathrm{w} / \mathrm{w})$ polihexanide to membranes composed of neutral phospholipids did not change their thermograms. However, in the presence of the acid phospholipid phosphatidylglycerol, $17 \%(\mathrm{w} / \mathrm{w})$ polihexanide shifted the phase transition temperature from 27 to $32^{\circ} \mathrm{C}$ and a second endothermic peak appeared in the thermogram at $-15.5^{\circ} \mathrm{C}$. This second peak indicated phase separation into a polihexanide-phosphatidylglycerol domain and a domain of neutral phospholipids. When polihexanide was replaced by diaminohexyl biguanide - a monomeric biguanide the phase transition temperature increased only slightly, but did not produce a second peak. The second peak effect was consistent with the observation that the monomeric biguanide did not precipitate phosphatidylglycerol but polihexanide.

Polihexanide species with amino end groups hydrolyze ester bonds of negatively charged substrates [11]. This catalytic activity may split phosphate ester bonds of negatively charged membrane phospholipids, leading to destabilization and disintegration of microbial membranes.

The findings of Ikeda's group [9-12] strongly suggest that phosphatidylglycerol and other negatively charged species of phospholipids are primary target sites of polihexanide on envelopes of microbes. The positively charged biguanide groups interact by electrostatic attraction with negatively charged phosphate head groups of these phospholipids. Polihexanide-phospholipid complex formation then induces an increase in membrane fluidity and permeability by (a) clustering of polihexanide-phospholipid complexes and neutral phospholipids in different domains, and (b) promoting interaction of hexamethylene spacer groups with the hydrophobic interior of the membrane bilayer. Complex formation and ensuing phase separation is facilitated by the chemical structure of polihexanide as the length of hexamethylene spacers is close to the distance between phospholipid head groups in artificial lipid monolayers. Polihexanide was also attached to liposomes mixed in a molar ratio of 4:1 from neutral phosphatidylcholine and the negatively charged lipid surrogate dihexadecyl phosphate, indicating a strong affinity of polihexanide for phosphate groups. This affinity is confirmed by precipitation of polihexanide incubated with sodium hexametaphosphate $\left(\mathrm{NaPO}_{3}\right)_{6}$ or other polymeric metaphosphates as reported by Kramer and Roth [24].

Initially, early experiments had indicated that the antimicrobial activity of polihexanide increased with increasing polymer length. Broxton et al. [25] assumed that larger polihexanide molecules produce larger domains and hence more membrane disruption, promoting rapid transfer of the biocide into E. coli cells. However, using different strains of E. coli, Gilbert et al. [26, 27] demonstrated that this trend was markedly reduced for polymer lengths $\geq 6$ when the bacteria were not stressed by centrifugation and/or osmotic shock during harvesting. In practice, the combination of small $(\mathrm{n}=4)$ and large $(\mathrm{n}=$ 35) oligomers revealed strong synergy. It was supposed that small oligomers initiate the disintegration of the cell wall and facilitate the passage of large oligomers into the cell.

The outer surface of bacteria is universally negatively charged and usually stabilized by divalent magnesium and calcium cations. Polihexanide replaces these ions and therefore has a natural affinity for the envelopes of both Gram-positive and Gram-negative bacteria and other microorganisms. Phosphatidylglycerol - the polihexanide target on experimental liposomes - is a main component in the membranes of Gram-negative E. coli (25\%) and Gram-positive Staphylococcus aureus (37\%) as reported by Ikeda et al. [9]. In addition to negatively charged acid phospholipids, other high-affinity binding sites for polihexanide are lipopolysaccharides in the outer membrane of Gram-negative bacteria, teichoic acids on the cell wall of Gram-positive bacteria, peptidoglycan components of the cell wall, and proteins of the cytoplasmic membrane. Yasuda et al. [28] showed that membrane 
permeabilization induced by polihexanide correlated in a dose-dependent manner with the release of lipopolysaccharides and the efflux of potassium ions. Evidence of binding to proteins and triggering intracellular signal pathways was shown by Allen et al. [29]. Using genome transcriptional profiling, these authors demonstrated changes of transcriptional rates of $E$. coli genes after exposure to bacteriostatic doses of polihexanide $(0.00075 \%$ or $7.5 \mathrm{mg} / \mathrm{l})$. Some of these changes were clustered around anti-stress genes responding to environmental insults.

\section{Polihexanide - Compared to Other Polycationic Antimicrobials}

Increasing worldwide proliferation of antibiotic-resistant microbes propelled research into new antibiotic agents. Besides polihexanide, a promising new class of antibiotics is synthetic polycationic peptides with positively charged lysin molecules at the carboxy-terminal end and amino acids with nonpolar side chains at the amino-terminal end. They are readily inserted into model bacterial lipid membranes containing negatively charged lipids but not into model mammalian lipid membranes containing neutral zwitterionic lipids and cholesterol. Results obtained by Glukhov et al. [30] support an initial electrostatic complex formation of peptide dimers onto the bacterial surface, followed by the sinking of the hydrophobic segment into the bacterial membrane. The orientation of hydrophobic segments was largely parallel to the membrane surface, and the deeper the peptide insertion into the membrane, the better the antimicrobial activity. When polycationic peptides included sequence motifs favoring dimerization or oligomerization, the bacterial membranes were more vulnerable. This effect can be explained by multiple-site attachment of oligomers thus enhancing the binding force to the membrane.

Comparing the action of polihexanide and polycationic peptides on the envelope of microbes, there are many similarities in the sequence of basic events, leading finally to the lethal action:

- attachment by electrostatic attraction to negatively charged target sites on the membrane and cell wall. Here, the polycationic antimicrobials influence the hydrophobic environment and functional configuration of membrane proteins and the release of lipopolysaccharides. According to the fluid mosaic model of the structure of cell membranes [31], these changes impair the proper function of ion pumps, receptors, or enzymes;

Polihexanide: A Safe and Highly Effective Biocide
- cross-linking of membrane molecules leading to reduced membrane fluidity and impeding lateral diffusion of lipids and proteins;

- sinking of nonpolar molecule segments into the hydrophobic interior of the membrane bilayer increases the distance between lipid molecules. At this point, the membrane integrity and its barrier function is affected and membrane permeability increases;

- the accumulation of adverse physiological effects finally causes membrane disruption and death of microbes.

Interestingly, the membrane of microbes is also the first target site for naturally occurring antimicrobial peptides. According to Zhu [32], these peptides appear early in eukaryotic evolution and are an integral part of the innate immune system in vertebrates, protecting mucous membranes against bacteria as well as fungi and even viruses, as shown recently [33]. Taylor et al. [34] analyzed the domains of the widespread $\beta$-defensins. These are small proteins characterized by a cationic and a hydrophobic domain and display both antimicrobial and chemoattractant activities. They consist of 15-20 amino acids, including a conserved cysteine motif and intramolecular disulfide bonds. The attachment of defensins to the cell membrane of microbes was studied [35]. In a first step, defensins are attached by electrical attraction, and the following second step is dependent on hydrophobicity and net charge of the cationic defensin. After the attachment is completed, defensins either form membrane pores or interact with negatively charged phospholipids or lipopolysaccharides. Pores and the role of selective efflux of ions and ATP in killing Candida albicans are discussed [36]. Using fluorescence-based biochemical assays, Sugiarto and Yu [37] demonstrated that ostrich $\beta$-defensins bound lipopolysaccharides and disrupted both outer and cytoplasmic membrane integrity of $E$. coli. Morgera et al. [38] studied the binding of human $\beta$-defensins to real and model membranes by biophysical methods. The results indicated binding to negatively charged phospholipids and insertion into the lipid bilayer. As discussed above for polihexanide, cross-linking of molecules and changes in the hydrophobic environment of proteins cause membrane disruption and finally cell death. The unique and characteristic composition of the envelope of microbes - coming into existence under extreme and anaerobic environmental conditions - make them vulnerable to the attack by polycationic agents, which in turn protect eukaryotic organisms efficiently against invading pathogenic microbes.

Skin Pharmacol Physiol 2010;23(suppl 1):7-16 


\section{Polihexanide - Effect on Biofilm}

Biofilm is the natural habitat of bacteria and is characterized by microcolonies embedded in a self-made matrix of biopolymers. The matrix offers a stable structure and shields the bacteria from biocides as well as host defense mechanisms. In patients with chronic infections, biofilm was found on different living tissues and often the opportunistic pathogens S. aureus and Pseudomonas aeruginosa were isolated [39]. Both are potent biofilmforming bacteria [40], and the latter is suspected of being responsible for the transition of infections into a chronic state [41]. In this context, the effect of an antiseptic on biofilm is a crucial feature.

Most extracellular biofilm matrices are predominantly composed of polysaccharides containing acid sugar units. The matrix of Pseudomonas consists mainly of mixed polymers of uronic acids (alginates) and the staphylococcal matrix of poly- $\mathrm{N}$-acetylglucosamine and extracellular teichoic acids. Seipp et al. [42] demonstrated that $0.1 \%$ polihexanide combined with $0.1 \%$ betaine surfactant $\left(\right.$ Prontosan ${ }^{\circledR}$ ) significantly reduced artificial biofilm of $P$. aeruginosa grown for 10 weeks on the inner surface of silicone tubing through which water flowed. The binding characteristics of polihexanide to acid polysaccharides depend on the concentration of the biocide, as shown by Blackburn et al. [43]. At lower concentrations, polihexanide is bound by electrostatic interactions, and as the concentration increases, hydrogen bonding becomes dominant. In sequence, these binding mechanisms may accumulate polihexanide in most biofilm matrices. Assuming the adsorption/desorption ratio is constant, the concentration of free polihexanide increases during accumulation, making the matrix more toxic for resident microorganisms. This view is supported by the inhibitory effect of polihexanide on the growth of Legionella in cooling water systems [44], where a high concentration of Legionella colony-forming units is associated with existing biofilm. Recently, it was shown that polihexanide combined with betaine surfactant (Prontosan) significantly reduced log colony-forming units per milliliter in experimental wounds inoculated with methicillin-resistant $S$. aureus and covered for $24 \mathrm{~h}$ to allow biofilm development [45].

\section{Polihexanide - State-of-the-Art Antiseptic}

In the past decade, increasing outbreaks of hospitalacquired infections caused by multidrug-resistant bacteria have become a serious problem worldwide. Selection of superbugs like multidrug-resistant Clostridium difficile, Mycobacterium tuberculosis, Serratia marcescens, Acinetobacter, and methicillin-resistant $S$. aureus or vancomycin-resistant Enteroccocus in hospital and nonhospital health care facilities was provoked by misuse of antibiotics either prophylactically or for treatment of minor ailments not shown to be bacterial. A prerequisite for containing the spread of superbugs is the rational use of antibiotics, which can be replaced in many cases by antiseptics, i.e. in wound care for treatment of contaminated wounds and infection prophylaxis. Polihexanide is a broad-spectrum biocide not only effective against Grampositive and Gram-negative bacteria, but also against Saccharomyces cerevisiae $[24,46]$, fungal (C. albicans, Aspergillus niger, Fusarium solani) $[47,48]$ and protozoal (Acanthamoeba spp.) [49-51] pathogens of infective keratitis, and against the enveloped virus HIV [52]. In treatment of chronic wounds, new products containing polihexanide (wound rinsing solutions, wound dressings, wound gels, and antiseptics) were used successfully to reduce infection rates $[4,53-55]$ and it is recommended by medical experts as a state-of-the-art antiseptic for chronic wounds [8].

The EPA (US Environmental Protection Agency) has classified polihexanide for general use [56]. The $\mathrm{LD}_{50}$ (lethal dose for $50 \%$ of the population) range of acute oral toxicity in 3 rat studies was $1,049-2,747 \mathrm{mg} / \mathrm{kg}$. In a rabbit developmental study, reduced number of litters, skeletal abnormalities, increased mortality and reduced food consumption were observed at a dietary dose of $40 \mathrm{mg} /$ $\mathrm{kg} /$ day. From these data, the no-observed-adverse-effect level for oral toxicity was estimated at $20 \mathrm{mg} / \mathrm{kg} / \mathrm{day}$ and both the acute and chronic reference dose at $0.2 \mathrm{mg} / \mathrm{kg} /$ day. The range of acute dermal toxicity in 3 rabbit studies was $>2,000$ to $>5,000 \mathrm{mg} / \mathrm{kg}\left(\mathrm{LD}_{50}\right)$. In an 80 -week dermal painting study in mice, body weight decreased and liver tumors developed at a dose of $750 \mathrm{mg} / \mathrm{kg} /$ day. From these data, the no-observed-adverse-effect level for short-, intermediate-, and long-term dermal use was estimated to be $150 \mathrm{mg} / \mathrm{kg} /$ day and the evidence of carcinogenicity 'not sufficient to assess human carcinogenic potential by oral and dermal routes'. In two studies, dermal sensitization was shown to be mild or moderate. There is no evidence of mutagenic, genotoxic, and neurotoxic effects of polihexanide in the EPA's database. In utero exposure studies did not indicate increased susceptibility of the fetus, and when adults were exposed in a two-generation reproductive study, there was no evidence of increased susceptibility of the offspring. 
The safety margin or therapeutic index of an agent describes the risk-benefit ratio for the patient. For an antibacterial, it is defined as the quotient of $\mathrm{LD}_{50}$ in rats and the minimum inhibitory concentration for a pathogen. The greater the difference between $\mathrm{LD}_{50}$ and minimum inhibitory concentration, the better the risk-benefit ratio. Considering the specific action of polihexanide on microbial envelopes, it is not surprising that the safety margin of polihexanide is far ahead of widely used antibiotics (table 2). Also the toxicity profile is excellent and superior to common antiseptics (table 3). Due to its effectiveness, broad-spectrum activity and excellent tolerance, polihexanide is considered to be an antiseptic of first choice, but it is contraindicated for treatment of cartilage and central nervous system [13].

\section{Polihexanide - Customer Applications}

Polihexanide was granted EPA re-registration in September 2005 [56] and is widely used in consumer applications and industrial processes:

- as a swimming pool sanitizer $\left(\right.$ Baquacil $^{\circledR}$, polihexanide concentration range $0.01-0.001 \%$ );

- for preservation of cosmetics (Cosmocil CQ, polihexanide concentration range $0.1-0.3 \%$ );

- for preservation of leather and hides (polihexanide concentration range $0.01-0.3 \%$ );

- as a contact lens disinfectant $(0.0001 \%$ polihexanide in combination with $0.1 \%$ EDTA, $0.06 \%$ borate acid, $0.25 \%$ poloxamer surfactants, etc.);

- as a disinfectant (cleanser) in agriculture and food handling (Vantocil IB, polihexanide concentration usually $0.1 \%$ );

- for treatment of hatching eggs to prevent Salmonella infection;
- for preservation of cellulosic fiber materials (mops, wipes, sponges) and recently as a finish to textiles (antimicrobial cellulose fibers);

- for preservation of aqueous technical fluids such as cutting and drilling oils, polymer lattices, mineral slurries, electrocoat resins, synthetic and proteinbased glues (polihexanide concentration range 0.01$0.5 \%)$.

In many of these applications, polihexanide had been used for decades without reports of adverse effects.

Recently mouthwash solutions containing polihexanide were launched for medical (ProntOral ${ }^{\circledR}$ ) and customer use (ProntoLind $\left.{ }^{\circledR}\right)$. Polihexanide $(0.12 \%)$ inhibits plaque recolonization and reduces bacterial counts on the tooth surface as shown in a double-blind randomized study [57]. These results were recently confirmed. A reduction of microbial vitality and de novo biofilm formation in the oral cavity by using polihexanide as mouthrinse was demonstrated [58].

Table 2. Safety margin of some common antiseptics compared to polihexanide

\begin{tabular}{lcc}
\hline Antiseptic & \multicolumn{2}{c}{$\begin{array}{l}\text { Oral } \mathrm{LD}_{50} \text { rat/minimum inhibitory } \\
\text { concentration, mmol/kg or mmol/l }\end{array}$} \\
\cline { 2 - 3 } & S. aureus & P. aeruginosa \\
\hline Benzalkonium chloride & 8.0 & 2.0 \\
Chlorhexidine & 0.9 & 0.9 \\
Octenidine & 3.2 & 3.2 \\
Polihexanide & 25,000 & 200 \\
PVP-iodine & 500 & 1,000 \\
\hline
\end{tabular}

Figures are calculated for 5 min incubation time in inhibition tests (according to Kramer [13]).

Table 3. Exploratory toxicological data of common antiseptics compared to polihexanide (adapted from Kramer [13])

\begin{tabular}{|c|c|c|c|c|c|c|c|}
\hline Antiseptic & $\begin{array}{l}\text { Irritation } \\
\text { skin }\end{array}$ & $\begin{array}{l}\text { Irritation mucosa/ } \\
\text { wound }\end{array}$ & $\begin{array}{l}\text { Allerge- } \\
\text { nicity }\end{array}$ & Toxicity & $\begin{array}{l}\text { Mutage- } \\
\text { nicity }\end{array}$ & Carcinogenicity & Teratogenicity \\
\hline $\begin{array}{l}\text { Benzalkonium chloride alkyl chain } \\
(\mathrm{n}=11,13,15,17)\end{array}$ & ++ & ++ & ++ & $+/++$ neurotoxic & - & $?$ & $?$ \\
\hline Chlorhexidine & + & $+/++$ & + & ++ neurotoxic & + & $\begin{array}{l}+ \text { premalignant } \\
\text { alterations }\end{array}$ & - \\
\hline Octenidine & \pm & $++/+++$ & - & $\begin{array}{l}+ \text { not for chronic } \\
\text { wounds }\end{array}$ & - & - & - \\
\hline Polihexanide & - & - & \pm & \pm & - & - & $(+)$ in non-use conc. \\
\hline PVP-iodine & - & $+/++$ & $+/++$ & + & - & - & - \\
\hline
\end{tabular}




\section{Polihexanide - Biological Fate in Vertebrates}

After oral injection of a single encapsulated dose of ${ }^{14} \mathrm{C}$-labelled polihexanide to the stomach of fish (Pollachius virens, $0.1 \mathrm{mg} / \mathrm{kg}$ fish), Christiansen and Palmork [59] determined the distribution and elimination of ${ }^{14} \mathrm{C}$ labelled material over a time period of 43 days. During the first 2 days, about $10 \%$ of the given radioactivity was found in the liver and about $2.5 \%$ in the muscle. Elimination from the liver was much higher compared to the muscle. At day 43 , only $2 \%$ of the total accumulated dose was left, but $40 \%$ in the muscle. Concentrations in the urine and bile were constantly low. However, considering the volume of urine production a substantial part of radioactivity might be excreted via the urine.

Bratt and Hathway [20] synthesized ${ }^{14} \mathrm{C}$-labelled polihexanide strictly similar to a commercial product ( $75 \%$ of polymer chains are made up of 2-5 monomer units) as proved by chromatographic methods. Rats were either given a single dose via a stomach tube or were chronically fed and killed at 1-week intervals. Elimination of ${ }^{14} \mathrm{C}$ by the urinary, fecal and pulmonary routes was studied. The main eliminative route was fecal (92-95\%), and only $5-6 \%$ of a single dose was excreted via the kidneys. Chronic administration led to temporary tissue concentrations of less than $0.3 \mathrm{ppm}$ in adipose depots and in the liver, kidneys and the heart. No evidence of biotransformation of polihexanide in rats was found, nor was the fecal ${ }^{14} \mathrm{C}$-labelled material metabolized by gut microorganisms.

The results of these feeding experiments showed that (a) the uptake of polihexanide in the intestinal tract is low, (b) the accumulation in organs and muscle is transient, (c) the main excretion route after uptake is the urine, and (d) there is no evidence of biotransformation in vertebrates.

\section{Polihexanide - Resistance and Biodegradation}

Polihexanide is adsorbed to the anionic bacterial envelope and damages cytoplasmic membranes. Due to the nonspecific action and the heterogeneity of polihexanide the potential to induce development of resistance should be - if any - very low, and in point of fact there are no reports about development of resistance. In the environment, polihexanide concentrations are reduced to nonbiocidal levels by adsorption to anionic surfaces of organic acids (i.e. humic acid) or acid minerals (i.e. phosphates). Therefore, polihexanide is less likely to trigger the development of resistant bacterial strains in the environment. In contrast, inactivation by adsorption may render polihexanide useful for some microorganisms as a source of nitrogen.

Until recently, there was only one report about biodegradation of polihexanide. Using the OECD $301 \mathrm{D}$ closed bottle test, Zöllner et al. [60] found a limited biodegradation rate of $13.5 \%$ after 28 days.

O'Malley et al. [61] isolated bacteria capable of utilizing polihexanide as the sole nitrogen source from sewage and enriched them by serial subculture in the presence of $0.009 \%$ polihexanide. Bacterial isolates from the final enrichment flask were separated by subculture on agar plates and subsequently assessed for their potential to use 3 species of 1.6-substituted hexanes. Interestingly, some bacterial isolates grew rapidly in culture media containing 1.6-diaminohexane or 1.6-diguanidohexane, while there was no growth in 1.6-di(cyanoguanidino)hexane medium (Klebsiella pneumoniae, P. putida, and Elizabethkingia meningoseptica). From these results, it was concluded that polihexanide flanked by cyanoguanidino-terminal groups may be insusceptible to biodegradation.

In another experiment, 2 consortia of bacteria utilizing polihexanide as the sole nitrogen source from sand filters of 2 different polihexanide-treated swimming pools were isolated [62]. Each consortium was enriched by serial subculture with increasing amounts of polihexanide, finally $0.1 \%$. In order to reduce the free concentration of polihexanide to nonbiocidal levels, an adsorbent (silica gel) was added to enrichment cultures. By feeding polihexanide with ${ }^{15} \mathrm{~N}$-labelled biguanide residues and analysis of ${ }^{15} \mathrm{~N}$-content of DNA samples, a biodegradation rate of about $28 \%$ was calculated for consortium 1 and of $21 \%$ for consortium 2. Single bacteria isolates - distinguished by colony morphology - were separated again from the final enrichment flasks by subculture on agar plates. From both consortia bacteria of the genera Sphingomonas and Azospirillum were isolated. Only the 3 sphingomonad isolates showed significant growth at the expense of polihexanide. However, growth yields increased manifold - probably by metabolic crossfeeding - when Azospirillum sp. was added to the cultures. The genus Sphingomonas has been shown to degrade other xenobiotic polymers [63], to cleave C-N bonds of polyaspartic acid [64], to degrade adsorbed substrates [65] and to transport polymers into the cytoplasm via a pit-dependent $A B C$ transporter [66]. These features may explain the uptake and metabolization of polihexanide by sphingomonads. 


\section{Conclusion}

Polihexanide is a broad-spectrum antiseptic with excellent tolerance and a low-risk profile. The physicochemical action on the bacterial envelope prevents or impedes the development of resistant bacterial strains. Thus, polihexanide is particularly suitable and useful in the struggle against multidrug-resistant bacteria. The ecological database is still incomplete. There is some evidence that biodegradation requires adsorption to inert surfaces and that only a small number of bacterial species are capable of utilizing polihexanide.

\section{Acknowledgement}

I would like to thank Dr. Thomas-Jörg Hennig for designing the molecular model of figure 1 .

\section{Disclosure Statement}

The author received financial support for research projects and consulting from B. Braun Medical AG, Switzerland, and Prontomed GmbH, Germany. Both companies are manufacturers of polihexanide-containing wound care products.

\section{References}

$>1$ Davies GE, Francis J, Martin AR, Rose FL, Swain G: 1:6-Di-4'-chlorophenyldiguanidohexane ('hibitane'); laboratory investigation of a new antibacterial agent of a high potency. Br J Pharmacol Chemother 1954;9: 192-196.

$>2$ Willenegger $\mathrm{H}$ : Lokale Antiseptika in der Chirurgie - eine Wiedergeburt? Unfallchirurg 1994;20:94-110.

3 Willenegger $\mathrm{H}$ : Klinische Erfahrungen mit einem neuen Antiinfektivum. Hyg Med 1994;19:227-233.

4 Kaehn K, Eberlein T: Polyhexanide (PHMB) and betaine in wound care management. EWMA J 2008;8:13-17.

$\checkmark 5$ Daeschlein G, Assadian O, Bruck JC, Meinl C, Kramer A, Koch S: Feasibility and clinical applicability of polihexanide for treatment of second-degree burn wounds. Skin Pharmacol Physiol 2007;20:292-296.

6 Gerli S, Rossetti D, Di Renzo GC: A new approach for the treatment of bacterial vaginosis: use of polyhexamethylene biguanide. A prospective, randomized study. Eur Rev Med Pharmacol Sci 2003; 7:127-130.

$>7$ Hansmann F, Kramer A, Ohgke H, Strobel H, Geerling G: Polyhexamethylbiguanid (PHMB) zur präoperativen Antisepsis bei Cataract Operation. Ophthalmologe 2004; 101:377-383.

8 Kramer A, Daeschlein G, Kammerlander G, Andriessen A, Aspöck C, Bergemann R, Eberlein T, Gerngross H, Görtz G, Heeg P, Jünger M, Koch S, König B, Laun R, Peter RU, Roth B, Ruef C, Sellmer W, Wewalka G, Eisenbeiss W: Konsensusempfehlung zur Auswahl von Wirkstoffen für die Wundantiseptik. Hyg Med 2004;5:147-157.

$>9$ Ikeda T, Tazuke S, Watanabe M: Interaction of biologically active molecules with phospholipid membranes. Fluorescence depolarisation studies on the effect of polymeric biocide bearing biguanides in the main chain. Biochim Biophys Acta 1983;735:380-386.
10 Ikeda T, Ledwith A, Bamford CH, Hann RA: Interaction of polymeric biguanide biocide with phospholipid membranes. Biochim Biophys Acta 1984;769:57-66.

11 Ikeda T, Tazuke S, Bamford CH: Interaction of membrane active biguanides with negatively charged species. A model of their interaction with target sites in microbial membranes. J Chem Res 1985;6:180-181.

12 Ikeda T, Tazuke S, Bamford CH, Ledwith A: Spectroscopic studies on the interaction of polymeric in-chain biguanide biocide with phospholipid membranes as probed by 8-anilinonaphthalene-1-sulphonate. Bull Chem Soc Jpn 1985;58:705-709.

13 Kramer A: Stellenwert der Infektionsprophylaxe und -therapie mit lokalen Antiinfektiva; in Kramer A, Wendt M, Werner HP (eds): Möglichkeiten und Perspektiven der klinischen Antiseptik. Wiesbaden, mhp, 1995, pp 15-25.

14 Frieling H, Gründling M, Lauer KS, Wendt M, Hackenberg T, Lehmann C, Pavlovic D: Intraperitoneal instillation of polihexanide produces hypotension and vasodilation: in vivo and in vitro study in rats. Int J Colorectal Dis 2006;21:373-383.

15 Berg A, Assadian O, Rudolph P, Mundkowski RG, Janda J, Kramer A: Intolerability to Lavasept ${ }^{\circledR}$ peritoneal lavage in experimentally induced peritonitis in the guinea pig. Hyg Med 2008;33:189-193.

16 Kramer A, Roth B, Müller G, Rudolph P, Klöcker N: Influence of the antiseptic agents polihexanide and octenidine on FL cells and on healing of experimental superficial aseptic wounds in piglets. A double-blind, randomised, stratified, controlled, parallelgroup study. Skin Pharmacol Physiol 2004; 17:141-146.

17 Körber A, Dissemond J: Polyhexanid schützt vor Kollagendegradierung: Erste Resultate einer in vitro Untersuchung zu Koll-P-10. ZfW 2007;4:213-216.
18 Langer S, Sedigh Salakdeh M, Goertz O, Steinau HU, Steinstraesser L, Homann HH: The impact of topical antiseptics on skin microcirculation. Eur J Med Res 2004;9:449_ 454.

19 Rose FL, Swain G: Bisdiguanides having antibacterial activity. J Chem Soc 1956;850: 4422-4425.

20 Bratt H, Hathway DE: Characterization of the urinary polymer-related material from rats given poly[biguanide-1,5-diylhexamethylene hydrochlorid]. Macromol Chem Phys 1976;177:2591-2605.

21 O’Malley LP, Hassan KZ, Brittan H, Johnson $\mathrm{N}$, Collins AN: Characterization of the biocide polyhexamethylene biguanide by matrix-assisted laser desorption ionization time-of-flight mass spectrometry. J Appl Polym Sci Symp 2006;102:4928-4936.

22 Kurzer F, Pitchfork ED: Biguanides. Berlin, Springer, 1968.

23 Davies A, Bentley M, Field BS: Comparison of the action of vantocil, cetrimide and chlorhexidine on Escherichia coli and its spheroplasts and the protoplasts of grampositive bacteria. J Appl Bacteriol 1968;31: 448-461.

24 Kramer A, Roth B: Polihexanid; in Kramer A, Assadian O (eds): Wallhäussers Praxis der Sterilisation, Desinfektion, Antiseptik und Konservierung. Qualitätssicherung der Hygiene in Industrie, Pharmazie und Medizin. Stuttgart, Thieme, 2008, pp 789-793.

25 Broxton P, Woodcock PM, Heatley F, Gilbert $\mathrm{P}$ : Interaction of some polyhexamethylene biguanides and membrane phospholipids in Escherichia coli. J Appl Bacteriol 1984;57: 115-124.

26 Gilbert P, Pemberton D, Wilkinson DE: Barrier properties of gram-negative cell envelope towards high molecular weight polyhexamethylene biguanides. J Appl Bacteriol 1990;69:585-592. 
-27 Gilbert P, Pemberton D, Wilkinson DE: Synergism within polyhexamethylene biguanide biocide formulations. J Appl Bacteriol 1990;69:593-598.

28 Yasuda K, Ohmizo C, Katsu T: Potassium and tetraphenylphosphonium ion-selective electrodes for monitoring changes in the permeability of bacterial outer and cytoplasmic membranes. J Microbiol Methods 2003. 54:111-115.

29 Allen MJ, White GF, Morby AP: The response of Escherichia coli to exposure to the biocide polyhexamethylene biguanide. $\mathrm{Mi}$ crobiology 2006;152:989-1000.

30 Glukhov E, Stark M, Burrows LL, Deber CM: Basis for selectivity of cationic antimicrobial peptides for bacterial versus mammalian membranes. J Biol Chem 2005;280:3396033967.

-31 Singer SJ, Nicolson GL: The fluid mosaic model of the structure of cell membranes. Science 1972;175:720-731.

-32 Zhu S: Evidence for myxobacterial origin of eukaryotic defensins. Immunogenetics 2007;59:949-954

-33 Smith JG, Nemerow GR: Mechanism of adenovirus neutralization by Human alphadefensins. Cell Host Microbe 2008;3:11-19.

- 34 Taylor K, Clarke DJ, McCullough B, Chin W, Seo E, Yang D, Oppenheim J, Uhrin D, Govan JR, Campopiano DJ, MacMillan D, Barran P, Dorin JR: Analysis and separation of residues important for the chemoattractant and antimicrobial activities of beta-defensin 3. J Biol Chem 2008;283:6631-6639.

- 35 Krishnakumari V, Nagaraj R: Interaction of antibacterial peptides spanning the carboxyterminal region of human beta-defensins 1-3 with phospholipids at the air-water interface and inner membrane of $E$. coli. Peptides 2008;29:7-14.

-36 Vylkova S, Sun JN, Edgerton M: The role of released ATP in killing Candida albicans and other extracellular microbial pathogens by cationic peptides. Purinergic Signal 2007; 3:91-97.

- 37 Sugiarto H, Yu PL: Mechanisms of action of ostrich beta-defensins against Escherichia coli. FEMS Microbiol Lett 2007;270:195200.

38 Morgera F, Antcheva N, Pacor S, Quaroni L, Berti F, Vaccari L, Tossi A: Structuring and interactions of human beta-defensins 2 and 3 with model membranes. J Pept Sci 2008;14: 518-523.

39 Donlan RM: Biofilms: microbial life on surfaces. Emerg Infect Dis 2002;8:881-890.

40 Gjødsbøl K, Christensen JJ, Karlsmark T, Jørgensen B, Klein BM, Krogfelt KA: Multiple bacterial species reside in chronic wounds: a longitudinal study. Int Wound J $2006 ; 1: 1-2$
Bjarnsholt T, Kirketerp-Møller K, Jensen PØ, Madsen KG, Phipps R, Krogfelt K, Høiby N, Givskov M: Why chronic wounds will not heal: a novel hypothesis. Wound Repair Regen 2008; 16:2-10.

42 Seipp HM, Hofmann S, Hack A, Skowronsky A, Hauri A: Efficacy of various wound irrigation solutions against biofilms. ZfW 2005;4: 160-164.

43 Blackburn RS, Harvey A, Kettle LL, Payne JD, Russell SJ: Sorption of poly(hexamethylene biguanide) on cellulose: mechanism of binding and molecular recognition. Langmuir 2006;22:5636-5644.

44 Kusnetsov JM, Tulkki AI, Ahonen HE, Martikainen PJ: Efficacy of tree prevention strategies against Legionella in cooling water systems. J Appl Microbiol 1997;82:763-768.

45 Perez R, Davis SC, Kaehn K: Wirkung verschiedener Wundspüllösungen auf MRSABiofilme in Wunden im Tiermodel. WundManagement 2010,4:44-48.

46 Elsztein C, de Menezes JAS, de Morais MA Jr: Polyhexamethyl biguanide can eliminate contaminant yeasts from fuel-ethanol fermentation process. J Ind Microbiol Biotechnol 2008;35:967-973.

-47 Messick CR, Pendland SL, Moshirfar M, Fiscella RG, Losnedahl KJ, Schriever CA, Schreckenberger PC: In-vitro activity of polyhexamethylene biguanide (PHMB) against fungal isolates associated with infective keratitis. J Antimicrob Chemother 1999; 44:297-298.

48 Liu N, Khong D, Chung SK, Hwang DG: Invitro susceptibility of ocular bacterial and fungal pathogens to polyhexamethylene biguanide. Invest Ophthamol Vis Sci 1996;37: 4058.

49 Larkin DFP, Kilvington S, Dart JKG: Treatment of Acanthamoeba keratitis with polyhexamethylene biguanide. J Ophthalmol 1992;99:185-191.

50 Donoso R, Mura JJ, Lopez M: Acanthamoeba keratitis treated with propamidine and polyhexamethylene biguanide (PHMB). Rev Med Chil 2002;130:396-401.

51 Narasimhan S, Madhavan HN, Therese LK: Development and application of an in vitro susceptibility test for Acanthamoeba species isolated from keratitis to polyhexamethylene biguanide and chlorhexidine. Cornea 2002; 21:203-205.

52 Krebs FC, Miller SR, Ferguson ML, Labib M, Rando RF, Wigdahl B: Polybiguanides, particularly polyethylene hexamethylene biguanide, have activity against human immunodeficiency virus type 1 . Biomed Pharmacother 2005;59:438-445.

53 Andriessen AE, Eberlein T: Assessment of a wound cleansing solution in the treatment of problem wounds. Wounds 2008;20:171-175.

54 Möller A, Kaehn K, Nolte A: Erfahrungen mit dem Einsatz polyhexanidhaltiger Wundprodukte bei der Versorgung chronischer Wunden - Ergebnisse einer systematischen retrospektiven Untersuchung an 953 Patienten. WundManagement 2008;3: 112-117.
55 Cazzaniga A, Serralta V, Davis S, Orr R, Eaglestein W, Mertz PM: The effect of an antimicrobial gauze dressing impregnated with 0.2 percent polyhexamethylene biguanides as a barrier to prevent $P$ seudomonas aeruginosa wound invasion. Wounds 2002;14:169-176.

56 United States Environmental Protection Agency: Reregistration eligibility decision of PHMB. EPA739-R-05-003, September 2005.

-57 Rosin M, Welk A, Kocher T, Majic-Todt A, Kramer A, Pitten FA: The effect of a polyhexamethylene biguanide mouthrinse compared to an essential oil rinse and a chlorhexidine rinse on bacterial counts and 4-day plaque re-growth. J Clin Periodontol 2002; 98:392-399.

58 Brecx M, Decker EM, Freitag HP, Maier G, von Ohle C: The effect of polihexanide on dental biofilm formation in vivo. J Dent Res 2008;87:0528.

59 Christiansen R, Palmork KH: Distribution and elimination of $\left[{ }^{14} \mathrm{C}\right]$ in saithe (Pollachius virens $\mathrm{L}$.) after application of a single dose of $\left[{ }^{14} \mathrm{C}\right]$ polyhexamethylene hydrochloridbiguanide. Bull Environ Contam Toxicol 1996; 36:121-128.

60 Zöllner H, Kramer A, Youssef P, Youssef U, Adrian V: Preliminary investigations on the biodegradability of selected microbicidal agents. Hyg Med 1995;20:401-407.

61 O'Malley LP, Collins AN, White GF: Biodegradability of end-groups of the biocide polyhexamethylene biguanide (PHMB) assessed using model compounds. I Ind Microbiol Biotechnol 2006;33:677-684.

62 O'Malley LP, Shaw CH, Collins AN: Microbial degradation of the biocide polyhexamethylene biguanide: isolation and characterization of enrichment consortia and determination of degradation by measurement of stable isotope incorporation into DNA. J Appl Microbiol 2007;103:1158-1169.

63 Kawai F: Sphingomonads involved in the biodegradation of xenobiotic compounds. J Ind Microbiol Biotechnol 1999;23:400-407.

64 Hiraishi T, Kajiyama M, Yamoto I, Doi Y: Enzymatic hydrolysis of alpha- and betaoligo(L-aspartic acid) by poly(aspartic acid) hydrolases-1 and 2 from Sphingomonas sp. KT-1. Macromol Biosci 2004;4:330-339.

65 Vacca DJ, Bleam WF, Hickey WJ: Isolation of soil bacteria adapted to degrade humic acidsorbed phenanthrene. Appl Environ Microbiol 2005;71:3797-3805.

- 66 Mishima Y, Momma K, Hashimoto W, Mikami B, Murata K: Super-channel in bacteria: function and structure of the macromolecule import system mediated by a pit-dependent $\mathrm{ABC}$ transporter. FEMS Microbiol Lett 2001;204:215-221. 